\title{
Development of an indoor air quality checklist for risk assessment of indoor air pollutants by semiquantitative score in nonindustrial workplaces
}

This article was published in the following Dove Press journal:

Risk Management and Healthcare Policy

12 April 2012

Number of times this article has been viewed

\author{
Al Syazwan' \\ B Mohd Rafee' \\ Juahir Hafizan² \\ AZF Azman' \\ AM Nizar ${ }^{3}$ \\ Z Izwyn ${ }^{4}$ \\ AA Muhaimin 5 \\ MA Syafiq Yunos ${ }^{6}$ \\ AR Anita' \\ J Muhamad Hanafiah' \\ MS Shaharuddin' \\ A Mohd Ibthisham ${ }^{7}$ \\ Mohd Hasmadi Ismail ${ }^{8}$ \\ MN Mohamad Azhar' \\ HS Azizan' \\ I Zulfadhli ${ }^{9}$ \\ J Othman 10
}

'Department of Community Health, Faculty of Medicine and Health Sciences, Universiti Putra Malaysia, Selangor, Malaysia; ${ }^{2}$ Department of Environmental Science, Faculty of Environmental Studies, Universiti Putra Malaysia, Selangor, Malaysia; ${ }^{3}$ Pharmacology Unit, Department of Human Anatomy, Faculty of Medicine and Health Sciences, Universiti Putra Malaysia, Selangor, Malaysia; ${ }^{4}$ Department of Therapy and Rehabilitation, Faculty of Health Science and Biomedical Engineering, Universiti Teknologi Malaysia, Johor, Malaysia; ${ }^{5}$ Department of Environmental Management, Faculty of Environmenta Studies, Universiti Putra Malaysia, Selangor, Malaysia;

${ }^{6}$ Plant Assessment Technology (PAT), Industrial Technology Division (BTI), Malaysian Nuclear Agency (Nuklear Malaysia), Bangi, Kajang, Malaysia; ${ }^{7}$ Department of Mechanical Engineering, Faculty of Mechanical Engineering, Universiti Teknologi Malaysia, UTM Skudai, Johor, Malaysia; ${ }^{8}$ Department of Forest Production, Faculty of Forestry, Universiti Putra Malaysia, Selangor, Malaysia; ${ }^{9}$ Faculty of Built Environment and Architect, Universiti Teknologi Malaysia, Skudai, Johor, Malaysia; ${ }^{10}$ Department of Counsellor Education and Counselling Psychology (DCECP), Faculty of Educational Studies, Universiti Putra Malaysia, Selangor, Malaysia

Correspondence: Aizat Ismail Syazwan Environmental and Occupational Medicine Unit, Department of Community Health, Faculty of Medicine and Health Sciences, Universiti Putra Malaysia, 43400, Serdang, Selangor, Malaysia Tel +60I3 2823757

Fax +60389450151

Email syazwan@putra.upm.edu.my
Background: To meet the current diversified health needs in workplaces, especially in nonindustrial workplaces in developing countries, an indoor air quality (IAQ) component of a participatory occupational safety and health survey should be included.

Objectives: The purpose of this study was to evaluate and suggest a multidisciplinary, integrated IAQ checklist for evaluating the health risk of building occupants. This IAQ checklist proposed to support employers, workers, and assessors in understanding a wide range of important elements in the indoor air environment to promote awareness in nonindustrial workplaces.

Methods: The general structure of and specific items in the IAQ checklist were discussed in a focus group meeting with IAQ assessors based upon the result of a literature review, previous industrial code of practice, and previous interviews with company employers and workers.

Results: For practicality and validity, several sessions were held to elicit the opinions of company members, and, as a result, modifications were made. The newly developed IAQ checklist was finally formulated, consisting of seven core areas, nine technical areas, and 71 essential items. Each item was linked to a suitable section in the Industry Code of Practice on Indoor Air Quality published by the Department of Occupational Safety and Health.

Conclusion: Combined usage of an IAQ checklist with the information from the Industry Code of Practice on Indoor Air Quality would provide easily comprehensible information and practical support. Intervention and evaluation studies using this newly developed IAQ checklist will clarify the effectiveness of a new approach in evaluating the risk of indoor air pollutants in the workplace.

Keywords: action checklist, aggregated risk index (ARI), qualitative, reliability, SME, enterprise, indoor environmental quality (IEQ), sick building syndrome, indoor air quality assessment

\section{Introduction}

Lack of assessment activities and studies on indoor air quality (IAQ) in many nonindustrial workplaces, especially in small and medium enterprises (SMEs), has been identified, and countermeasures have been discussed nationally and worldwide in this century. ${ }^{1}$ In Malaysia, legislation started in early 2005 when the Department of Occupational Safety and Health (DOSH) under the Ministry of Human Resources launched a Code of Practice on Indoor Air Quality (2005), which primarily aimed to ensure that employers work voluntarily in assessing risks of IAQ in the workplace. ${ }^{2}$ After 5 years, in August 2010, the DOSH in Malaysia introduced new and extensive legislation named the Industry Code of Practice on Indoor Air Quality (ICOP-IAQ), which was approved by the Minister on August 30, 2010 and thus replaced the 2005 version. ${ }^{3}$ However, even in 2005, IAQ, especially in the office environment, was a concern mainly only in relation 
to major issues such as comfort ${ }^{4,5}$ and energy consumption, ${ }^{6,7}$ rather than health-related issues, especially in SMEs. ${ }^{8}$ On the other hand, many multinational companies in the oil and gas industry led the initiative in assessing the risk of the exposure of workers indoors. In 2010, the Malaysian Government took several measures to promote IAQ assessment of risk-related issues in SMEs. ${ }^{3,9}$ Regional occupational health centers such as the National Institute of Occupational Safety and Health (NIOSH) and the Malaysian Industrial Hygiene Association were established to guide and provide information regarding awareness programs and specific certification procedures for professional IAQ assessors. ${ }^{9}$ All this effort since 2004-2005 until 2010 was driven to support small companies with fewer than 50 employees. ${ }^{2}$ Several talks and seminars were conducted by the NIOSH and other private companies to promote OSH activities in SMEs, focusing on nonindustrial workplaces. However, these measures have not been fully utilized, ${ }^{10}$ and new approaches to promoting IAQ awareness need to be improved in order to promote healthy indoor workplaces. ${ }^{11}$

Malaysian researchers have described and listed several vital components related to the importance of IAQ assessment in commercial buildings and sick building syndrome (SBS) occurrences. ${ }^{1,9-12}$ Although the risk of indoor air pollution leads to significant risk of developing SBS symptoms under poor ventilation and thermal comfort adjustment, we believe that many other factors need to be investigated in order for us to understand SBS etiology. ${ }^{13}$ To our current knowledge, more than 100 buildings have been inspected by IAQ assessors since the Code of Practice on Indoor Air Quality was published by the DOSH in 2005. ${ }^{2}$ However, the question is why so many other related industries besides oil and gas do not conduct IAQ study/assessment in their premises.

The researcher suggests that one of the important issues in conducting IAQ assessment is budget constraints and limited resources of expertise. ${ }^{9,10}$ Therefore, in 2010, an updated version of the ICOP-IAQ was published, which is more concerned with the major responsibilities of the employer to ensure that the air quality of the indoors environment is up to standard, and with the need to engage professional IAQ assessors who have an understanding of building problems. No extensive studies were conducted to assess the acceptability of the new ICOP-IAQ in evaluating this concern. Due to the rapid growth of the Malaysian population, there is an urge to develop awareness of identifying the risks of pollutants that exist in the indoor environment.

Previous studies have suggested few indicators that may lead to changes of health status among workers. ${ }^{6,7}$ However, there is a lack of published material characterizing risk using qualitative or integrated methods. Due to constraints of budget or funding, some commercial buildings fail to perform such inspections and react only when a problem arises among the employees (such as mold growth). ${ }^{13}$ Therefore, it is viewed as important to produce a validated and reliable checklist for assessing risks of indoor environments by utilizing the concept of semiquantitative elements and adaptation from the current ICOP-IAQ.

An action checklist has been developed previously by developed countries such as Japan, ${ }^{8,14,15}$ Korea, ${ }^{16}$ and the US/ Europe, ${ }^{17}$ and many countries have proven it to be effective in facilitating concrete actions for improvements, especially in SMEs in Asia. ${ }^{4,18,19}$

More recent action checklists have focused on general health and safety in observed and clear risks and hazards. Not many studies have been conducted to develop action checklists for IAQ, due to limited funding and budget constraints. Therefore, there is a need for a comprehensive and reliable tool for assessing the risks that exist in the indoor environment. This method (using an IAQ checklist) will help in identifying the need for further quantitative assessment (detailed measurement of airborne pollutants) to be later decided on by the management group and in relation to cost. ${ }^{4,18,20}$

The main objective of this study is to develop a new multidimensional IAQ checklist that can support employers and workers in understanding the value of a wide range of indoor pollutants and building science elements in promoting participatory OSH in nonindustrial workplaces, especially in SME application.

\section{Materials and methods}

\section{Literature review}

The previous checklist published by the DOSH in Malaysia ${ }^{2,3}$ was reviewed, and the items were extracted and categorized. Other input from current research findings related to IAQ in nonindustrial workplaces in Malaysia was reviewed. Other information related to IAQ investigation methods gathered through journals, DOSH reports, and related coursework taught by an approved certification body such as the NIOSH and the Malaysian Industrial Hygiene Association was included in the category.

\section{Extraction of essential information for scoring the risk of indoor air pollutants}

Information that tended to be lacking but which was essential to meet the IAQ checklist has been drawn from the results of interviews of certified professional IAQ assessors in Malaysia. Experienced industrial hygiene technician experiences were 
also included in the development and extraction of important components in checklist development. Numerical scores were included in the scale as an indicator. The higher the risk, the higher the score (and vice versa).

\section{Focus group meeting on the general structure of the new indoor air checklist}

The whole structure of our new approach was discussed in several rounds of focus group meetings with OSH practitioners, OSH professionals, IAQ assessors, researchers, occupational health doctors, occupational hygienists, and hygiene technicians.

\section{Formulating the new multidimensional indoor air checklist}

Essential technical areas were extracted during several rounds of the focus group meetings mentioned previously. Consequently, we prepared an item pool for each technical area, incorporating terms used by our interviewees and from the previous checklist. Essential items in the checklist were then selected for each technical area.

\section{Validity and practicality}

To ensure the practicality and validity of the new multidimensional IAQ checklist, several sessions were held to discuss the content and descriptions of the technical areas and items within each area with employers, workers, OSH researchers, and consultants, including IAQ assessors. After several rounds of discussion to obtain various opinions, an acceptable version of the action checklist was completed.

\section{Semiquantitative approach in characterizing risk: trial of indoor air checklist among selected OSH professionals}

According to a mold study, ${ }^{13}$ the element of scoring can be identified using numerical numbers based on the severity concept of the pollutants that exist. Using the appropriate literature and concept, a numerical score was given to characterize the degree of exposure in terms of quantitative evaluation that needed to be identified by the IAQ assessor.

To evaluate the acceptability of the checklist, a test was conducted among $21 \mathrm{OSH}$ professionals registered under the NIOSH program. Analysis of the data gathered from the scoring method was computed into each technical area. Statistical analysis was performed using Kuder-Richardson coefficient, a variant of the $\alpha$ coefficient. ${ }^{21}$ This test was used to measure the internal consistency of domains and total score of the IAQ checklist.
Landis and $\mathrm{Koch}^{22}$ criteria were used to characterize reliability levels as follows: $0-0.4$ poor, $0.41-0.74$ from fair to good, and 0.75-1 excellent. Analyses were carried out using SPSS for Windows (v 15.0; SPSS Inc, Chicago, IL).

\section{Results General structure}

As to the general structure, combined use of the action checklist, regulated under the ICOP-DOSH with the information guidebook and discussion from OSH professional bodies in Malaysia, was planned for effective introduction of essential information on multidimensional IAQ checklists in evaluating the risk of working indoors. The newly developed multidimensional checklist itself was intended to be simple and easily understood by non-OSH professional personnel. This was to ensure that the employees had the chance to make complaints to the building owner if risks of working in the indoor environment were present. The information guidebook with the latest ICOP also included basic knowledge and concrete ideas for promoting good IAQ in nonindustrial workplaces and other related indoor space for supporting good IAQ in buildings, which are quite diversified and a new field in Malaysia.

\section{New multidimensional indoor air checklist}

The new multidimensional IAQ checklist that was formulated consists of seven core areas, nine technical areas, and 71 essential items (Table 1). In addition to the technical areas covered from the previous ICOP checklist, several new areas were suggested for improving the IAQ checklist. The constructed IAQ checklist, based on the literature and discussion with the OSH professionals, identified the main items in characterizing risk influencing IAQ as pollution, ventilation, human exposure to pollutants, and other factors.

\section{Linkage with the information guidebook and ICOP}

Each section of the IAQ checklist was linked to the suitable item in the ICOP as regulated by the DOSH, which was originally developed and edited so that each chapter corresponded to the core area of the IAQ checklist (Table 1). The detail of reliability of the IAQ checklist in predicting risk of IAQ pollutants will be reported in the future.

A flow chart describes how to use the IAQ checklist (Figure 1), and the manifesto of selected actions was prepared in order to characterize risk of IAQ pollution in nonindustrial workplaces (offices) (Figure 2). 
Table I The content of the new multidimensional action checklist for evaluating indoor air quality

\begin{tabular}{|c|c|c|c|c|c|}
\hline Code & Core areas & Section & Technical areas/term & $\begin{array}{l}\text { Number } \\
\text { of essential items }\end{array}$ & Example of the items \\
\hline I. & $\begin{array}{l}\text { General indoor } \\
\text { environment }\end{array}$ & A & $\begin{array}{l}\text { Odor and general visible } \\
\text { inspection during } \\
\text { walkthrough }\end{array}$ & 15 & $\begin{array}{l}\text { Assessor inspection } \\
\text { Asking about the odor of the workplace } \\
\text { whether acceptable or not } \\
\text { Determine basic observed condition } \\
\text { of workplace (office) such as leakage, } \\
\text { ventilation diffuser, and possible } \\
\text { pollutants exist }\end{array}$ \\
\hline \multirow[t]{2}{*}{ II. } & $\begin{array}{l}\text { Human exposure } \\
\text { and comfort level }\end{array}$ & B & $\begin{array}{l}\text { Estimation of the occupancy } \\
\text { rate in the work area/s }\end{array}$ & 2 & $\begin{array}{l}\text { The identification of workspace } \\
\text { requirement } \\
\text { Evaluating the space within the workplace } \\
\text { and any evidence of unsuitable conditions }\end{array}$ \\
\hline & & C & $\begin{array}{l}\text { Utilized the comfort } \\
\text { and perceived indoor } \\
\text { environmental problem } \\
\text { (if any) }\end{array}$ & 9 & $\begin{array}{l}\text { Evidence of the indoor environment } \\
\text { conditions } \\
\text { Characterization of the location } \\
\text { and condition associated with the risk } \\
\text { of indoor air pollutants and possible } \\
\text { hazard to workers } \\
\text { Evaluation of the workers' perception } \\
\text { regarding the indoor environment } \\
\text { condition by looking at the behavioral } \\
\text { practice toward adapting the indoor } \\
\text { environment }\end{array}$ \\
\hline \multirow[t]{2}{*}{ III. } & $\begin{array}{l}\text { Potential source } \\
\text { of contaminants }\end{array}$ & $\mathrm{D}$ & $\begin{array}{l}\text { Occupant attitude toward } \\
\text { smoking and other common } \\
\text { source of pollutants }\end{array}$ & 4 & $\begin{array}{l}\text { Establishing the pollutants inventory } \\
\text { Establishing the pollutants inventory } \\
\text { (including smoking activity) to easily identify } \\
\text { the possible pollutants that may influence } \\
\text { the indoor air quality in workplace }\end{array}$ \\
\hline & & $\mathrm{E}$ & Potential prescribed activities & 8 & $\begin{array}{l}\text { Identification of activities that may } \\
\text { pose health risk effects during normal } \\
\text { building operations } \\
\text { Tracing any prescribed activities leading } \\
\text { to health-related risk: eg, renovation and } \\
\text { installation of new air-conditioning system }\end{array}$ \\
\hline IV. & $\begin{array}{l}\text { Ventilation and } \\
\text { air-conditioning } \\
\text { system }\end{array}$ & $\mathrm{F}$ & $\begin{array}{l}\text { Evaluation of ventilation } \\
\text { and air-conditioning system } \\
\text { condition as manufactured } \\
\text { specification }\end{array}$ & 18 & $\begin{array}{l}\text { Gathering information on mechanical } \\
\text { ventilation and air-conditioning system } \\
\text { Find useful information about the operation } \\
\text { and maintenance of mechanical ventilation } \\
\text { and air-conditioning system that serves } \\
\text { the occupant workspace } \\
\text { Collection of evidence that shows possible } \\
\text { risk of generating poor indoor air quality }\end{array}$ \\
\hline V. & $\begin{array}{l}\text { Perception } \\
\text { of indoor air quality } \\
\text { in outdoors }\end{array}$ & G & $\begin{array}{l}\text { Comparison of air quality } \\
\text { in outdoors }\end{array}$ & 3 & $\begin{array}{l}\text { Gathering information regarding } \\
\text { outdoor air status } \\
\text { Provide sufficient evidence regarding } \\
\text { the outdoor air condition that may influence } \\
\text { indoor environment }\end{array}$ \\
\hline VI. & $\begin{array}{l}\text { Perception } \\
\text { of indoor air quality } \\
\text { in indoors }\end{array}$ & $\mathrm{H}$ & $\begin{array}{l}\text { Perceived indoor air quality } \\
\text { stated by occupants }\end{array}$ & 5 & $\begin{array}{l}\text { Evidence of occupant complaint } \\
\text { and discomfort } \\
\text { Find the general perceived feeling by the } \\
\text { occupant toward working in the particular } \\
\text { workplace }\end{array}$ \\
\hline VII. & $\begin{array}{l}\text { Industry Code } \\
\text { of Practice on Indoor } \\
\text { Air Quality } 2010\end{array}$ & I & $\begin{array}{l}\text { Understanding of indoor } \\
\text { air quality-related guideline }\end{array}$ & 7 & $\begin{array}{l}\text { Understanding about the related } \\
\text { regulation } \\
\text { Promote health and safety activities that can } \\
\text { improve the indoor air quality in workplace }\end{array}$ \\
\hline & Sum & & 9 & 71 & \\
\hline
\end{tabular}




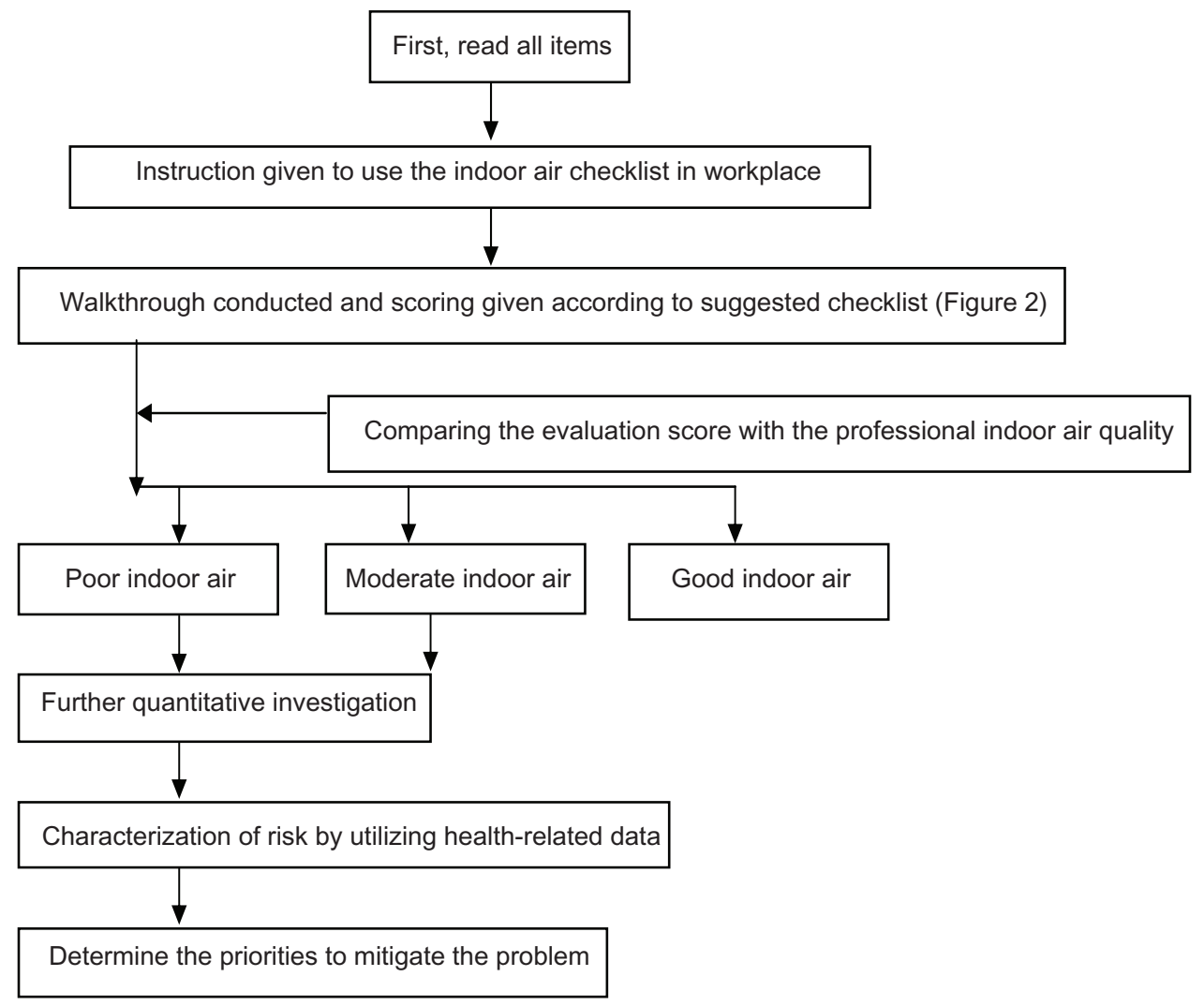

Figure I Description of suggested process in using the checklist for occupational safety and health practitioner/building occupants in characterizing the condition of the workplace.

\section{Reliability result among OSH professionals}

Table 2 shows the results of reliability analysis among selected OSH professionals tested in the NIOSH. Based on the results, the overall condition of items included in the checklist seemed to give a high reliability score for determining the condition of the indoor environment. From nine components only two recorded low reliability scores, namely understanding the IAQ-related guideline and utilization of comfort and perceived indoor environmental problems (if any).

\section{Discussion}

With increasing attention and a newly updated ICOP-IAQ by the DOSH, participatory approaches to IAQ issues have become essential in recent years. ${ }^{1-3}$ An action checklist for IAQ risk identification has been proven to be the most efficient tool for promoting participative indoor workplace improvement and is expected to bring a voluntary initiative to nonindustrial workplace areas for workplace health promotion. On the other hand, published IAQ checklists have been restricted to "yes" or "no" answers, which focus only on finding absolute and no numerical weightage in calculating the cumulative risk present. ${ }^{3-5}$ Quite recently, a new action checklist on OSH has been developed. ${ }^{4,23,24}$

The present study tried to extend and evaluate the usefulness of existing checklists to cover all aspects of the indoor air environment to be evaluated in nonindustrial workplaces such as offices, schools, and public places.



Figure 2 Example of the checklist for scoring method of risk in evaluating indoor air quality. 
Table 2 Score of reliability as function of the code given by selected occupational safety and health professional

\begin{tabular}{|c|c|c|}
\hline Code & Item name & Score reliability \\
\hline A & $\begin{array}{l}\text { Odor and general visible inspection } \\
\text { during walkthrough }\end{array}$ & $0.577^{* *}$ \\
\hline B & $\begin{array}{l}\text { Estimation of the occupancy rate } \\
\text { in the work area/s }\end{array}$ & $0.64 I^{* *}$ \\
\hline C & $\begin{array}{l}\text { Utilized the comfort and perceived } \\
\text { indoor environmental problem (if any) }\end{array}$ & $0.426^{*}$ \\
\hline D & $\begin{array}{l}\text { Occupant attitude toward smoking } \\
\text { and other common source } \\
\text { of pollutants }\end{array}$ & $0.894 * * *$ \\
\hline$E$ & Potential prescribed activities & $0.870 * * *$ \\
\hline $\mathrm{F}$ & $\begin{array}{l}\text { Evaluation of ventilation and } \\
\text { air-conditioning system condition } \\
\text { as manufactured specification }\end{array}$ & $0.707^{* *}$ \\
\hline G & Comparison of air quality in outdoors & $0.774 * *$ \\
\hline $\mathrm{H}$ & $\begin{array}{l}\text { Perceived indoor air quality stated } \\
\text { by occupants }\end{array}$ & $0.522 *$ \\
\hline I & $\begin{array}{l}\text { Understanding of indoor air } \\
\text { quality-related guideline }\end{array}$ & $0.432 *$ \\
\hline
\end{tabular}

Notes: *Poor: 0-0.4; **fair/good: 0.4I-0.74; ***good/excellent: 0.75-I.

This newly developed action checklist will help the building owner to decide whether further IAQ assessment is needed to ensure that a healthy indoor environment has been achieved. Our previous interviews and case studies reported that employers and OSH professionals had some difficulty in characterizing the risk that exists in the indoor environment as a growing concern with OSH legislation since 1994. Employers and OSH representatives in companies have also indicated that they had much less knowledge of the health perspective than the safety perspective, while most of the time the indoor environment was "assumed" to be good. This new action IAQ checklist will support the decision maker and building owner to consider the first phase of participatory occupational health activities and related monitoring that will lead to the appropriate use of health care resources, industrial hygiene specialists, and consultants.

With the expansion of covered risks related to indoor pollutants items with a numerical score, the new multidimensional action IAQ checklist should provide wider information in characterizing risk by adapting a relevant guide in previous literature ${ }^{25-27}$ than the existing checklist under the ICOP. Especially with regard to the health perspectives, it is important that workers and employers can easily consult industrial hygiene professionals or IAQ assessor specialists outside the company when needed. Current data indicate that the total numbers of certified assessors in this country were fewer than 25 personnel ${ }^{28}$ and show the need for evaluation of IAQ in the country to characterize problematic buildings to be mitigated before health issues arise. On the other hand, this new IAQ checklist should be simple enough to be easily read and comprehended. As a measure to solve this dilemma, we planned the combined use of the IAQ checklist and the ICOP.

Trained facilitators will increase the effectiveness of this IAQ checklist. We intend to utilize site visit opportunities fully not only for individual support (commonly all responsible under the health and safety officer) but also for organizational support. As a developing country, staff in health and safety groups are trained via special IAQ courses that are suitable to facilitate activities related to IAQ and meet the company's initiative toward their capabilities.

A comparison and evaluation study will be needed to evaluate the practicality and effectiveness of this support tool in evaluating the IAQ risk present in the workplace. ${ }^{29,30} \mathrm{We}$ have started the evaluation study using this newly developed IAQ checklist with the ICOP, and with training by IAQ specialists as facilitators. Now we are collecting process records, not only in the case of success and reliability of this checklist for preliminary evaluation of IAQ risk but also to improve the model and tools through information gained from experience.

This checklist will be further used as one of the important risk determinations by adapting aggregated risk index, as discussed previously by European researchers. ${ }^{31}$ The index suggested use of the numerical form to reflect the contribution of individual pollutants to total risk, thus corresponding with the time-averaged concentrations $\left(\mathrm{mg} / \mathrm{m}^{3}\right)$, and should be integrated with coefficient of the incremental risk values (relative risk). The checklist will be useful and beneficial among occupational health practitioners in addressing IAQ issues in indoor environments and for integration with other environmental factors such as noise, vibration, lighting, thermal comfort, ${ }^{32}$ and ergonomics.

\section{Conclusion}

The newly developed IAQ checklist will be one of the key elements in identifying risk elements for the evaluation of indoor air pollutants in indoor environments and will highlight the need for IAQ assessment in workplaces.

\section{Acknowledgments}

This research was funded by the OSH management office of Universiti Putra Malaysia. The authors would like to thank Maznah Ab Jamal for her guidance toward the publication 
of this article. Special thanks also go to Ismail Musa, Mohd Khairi Ismail, and Hasanul Manzar Ismail for their ideas and critical evaluation of this article.

\section{Disclosure}

The authors report no conflicts of interest in this work.

\section{References}

1. Syazwan Aizat I, Juliana J, Norhafizalina O, Azman ZA, Kamaruzaman J. Indoor air quality and sick building syndrome in Malaysian buildings.

2. Department of Occupational Safety and Health. Ministry of Human Resources. Code of practice on indoor air quality. 2005. JKKP GP (1) 05/2005. ISBN 983-2014-51-4. Available from: http://www.dosh. gov.my/doshV2/phocadownload/CodeOfPractice/codeofpracticeonin doorairquality.pdf. Accessed February 24, 2012.

3. Department of Occupational Safety and Health. Ministry of Human Resources. Industry code of practice on indoor air quality. 2010. JKKP DP (S) 127/379/4-39. ISBN 983201471-3.

4. Simonson CJ, Salonvaara M, Ojanen T. The effect of structures on indoor humidity: possibility to improve comfort and perceived air quality. Indoor Air. 2002;12(4):243-251.

5. Melikov AK, Kaczmarczyk J. Air movement and perceived air quality. Build Environ. 2012;47(1):400-409.

6. Turiel I, Hollowell CD, Miksch RR. The effect of reduced ventilation on indoor air quality in an office building. Atmos Environ. 1983; 17(1):51-64.

7. Lagoudi A, Loizidou M, Santamouris M, Asimakopoulos D. Symptoms experienced, environmental factors and energy consumption in office buildings. Energy and Building. 1996;24(3):237-243.

8. Nishikido N, Yuasa A, Motoki C, et al. Development of multidimensional action checklist for promoting new approaches in participatory occupational safety and health in small and medium-sized enterprises. Industrial Health. 2006;44:35-41.

9. Ismail SH, Deros MB, Leman AM. Indoor air quality issues for nonindustrial work place. International Journal of Research and Reviews in Applied Sciences. 2010;5(3):235-244.

10. Sulaiman Z, Mohamed M. Indoor air quality and sick building syndrome study at two selected libraries in Johor Bahru, Malaysia. Environment Asia. 2011;4:67-74.

11. Kavitha M, Jalaludin J, Abdah Md A, Zarida H, Shamsul BMT, Syazwan AI. Human sputum interleukin- 6 by exposure to $\mathrm{PM}_{10}$ among bus drivers in Klang Valley. J Appl Sci. 2010;10(4):269-276.

12. Ismail M, Zafirah Mohd Sofian N, Abdullah AM. Indoor air quality in selected samples of primary schools in Kuala Terengganu, Malaysia. Environment Asia. 2010;3:103-108.

13. Park JH, Schleiff PL, Attfield MD, Cox-Ganser JM, Kreiss K. Building-related respiratory symptoms can be predicted with semiquantitative indices of exposure to dampness and mold. Indoor Air. 2004; 14(6):425-433.

14. Zeimet D, Ballard D, Mai K. A comprehensive safety and health program for the small employer. Occup Health Saf. 1997;66:127-133.

15. Hasle P, Limborg JJ. A review of the literature on preventive occupational health and safety activities in small enterprises. Ind Health. 2006;44:6-12. Glob J Health Sci. 2009;1(2):126-136.

16. Park H, Cho KS, Lee SH, Meng K. Evaluation of occupational health services in small- and medium-sized industries in Korea. Int Arch Occup Environ Health. 2001;74:68-78.

17. Mendell MJ. Indices for IEQ and building-related symptoms. Indoor Air. 2003;13(4):364-368.

18. Krungkraiwong S, Itani T, Amornratanapaichit R. Promotion of a healthy work life at small enterprises in Thailand by participatory methods. Ind Health. 2006;44:108-111.

19. Kogi K. Work improvement and occupational safety and health management systems: common features and research needs. Ind Health. 2002;40:121-133.

20. Parker DL, Brosseau LM, Samant Y, Xi M, Pan W, Haugan D. A randomized, controlled intervention of machine guarding and related safety programs in small metal-fabrication businesses. Public Health Rep. 2009;124(Suppl 1):90-100.

21. Nunnally JC, Bernstein IH. Psychometric theory, 3rd ed. New York: McGraw-Hill; 1994.

22. Landis JR, Koch GG. The measurement of observer agreement for categorical data. Biometrics. 1977;33(1):159-174.

23. Kinchington M, Ball K, Naughton G. Reliability of an instrument to determine lower limb comfort in professional football. Open Access Journal of Sports Medicine. 2010;1:77-85.

24. Baccarini D, Archer R. The risk ranking of projects: a methodology. International Journal of Project Management. 2001;19(3):139-145.

25. De Vente J, Poesen J, Verstraeten G. The application of semi-quantitative methods and reservoir sedimentation rates for the prediction of basin sediment yield in Spain. Journal of Hydrology. 2005; 305(1-4):63-86.

26. Perez T, Arnould B, Grosbois J, Bosch V, Guillemin I. Validity, reliability, and responsiveness of a new short Visual Simplified Respiratory Questionnaire $\left(\mathrm{VSRQ}^{\circledR}\right)$ for health-related quality of life assessment in chronic obstructive pulmonary disease. Int J Chron Obstruct Pulmon Dis. 2009;4:9-18.

27. Bergus GR, Woodhead JC, Kreiter CD. Using systematically observed clinical encounters (SOCEs) to assess medical students' skills in clinical settings. Adv Med Educ Pract. 2010;1:67-73.

28. Indoor Air Quality Assessor Registered with Department of Occupational Safety and Health (DOSH), Malaysia under Industry Code of Practice on Indoor Air Quality (ICOP-IAQ), 2010. Available from: http://www.dosh. gov.my/doshv2/Senarai/OYK/iaq/list_iaq.php?id=10. Accessed March 20, 2012. Malaysian.

29. Skyberg K, Skulberg KR, Eduard W, Skåret E, Levy F, Kjuus H. Symptoms prevalence among office employees and associations to building characteristics. Indoor Air. 2004;3(3):246-252.

30. Kogi K. Participation as precondition for sustainable success: effective workplace improvement procedures in small-scale sectors in developing countries. Corporate sustainability as a challenge for comprehensive management. In: Zink KJ, editor. Heidelberg, Germany: Physica-Verlag; 2008:183-198.

31. Sicard P, Lesne O, Alexandre N, Mangin A, Collomp R. Air quality trends and potential health effects: development of an aggregate risk index. Atmos Environ. 2011;45(5):1145-1153.

32. COST European Cooperation in Scientific and Technical Research. Universal Thermal Climate Index, COST Action 730. Available from: http://www.utci.org/cost.php. Accessed February 24, 2012.

\section{Dovepress}

\section{Publish your work in this journal}

Risk Management and Healthcare Policy is an international, peerreviewed, open access journal focusing on all aspects of public health, policy, and preventative measures to promote good health and improve morbidity and mortality in the population. The journal welcomes submitted papers covering original research, basic science, clinical \& epidemio- logical studies, reviews and evaluations, guidelines, expert opinion and commentary, case reports and extended reports. The manuscript management system is completely online and includes a very quick and fair peerreview system, which is all easy to use. Visit http://www.dovepress.com/ testimonials.php to read real quotes from published authors. 